Research Article

\title{
Variability in Prolificacy, Total Carotenoids, Lutein, and Zeaxanthin of Yellow Small-Ear Waxy Corn Germplasm
}

\author{
Supaporn Sukto $\mathbb{D}^{1,2}$ Khomsorn Lomthaisong, ${ }^{3}$ Jirawat Sanitchon, ${ }^{1,4}$ \\ Sompong Chankaew, ${ }^{1,4}$ Marvin P. Scott, ${ }^{5}$ Thomas Lübberstedt, ${ }^{6}$ Kamol Lertrat, ${ }^{4}$ \\ and Bhalang Suriharn ${ }^{1,4}$ \\ ${ }^{1}$ Department of Agronomy, Faculty of Agriculture, Khon Kaen University, Khon Kaen 40002, Thailand \\ ${ }^{2}$ Uthai Thani Agricultural Research and Development Center, Department of Agriculture (DOA), Uthai Thani 61110, Thailand \\ ${ }^{3}$ Department of Biochemistry, Faculty of Science, Khon Kaen University, Khon Kaen 40002, Thailand \\ ${ }^{4}$ Plant Breeding Research Center for Sustainable Agriculture, Khon Kaen University, Khon Kaen 40002, Thailand \\ ${ }^{5}$ USDA-ARS Corn Insects and Crop Genetics Research Unit, USDA-ARS, Ames, IA 50011, USA \\ ${ }^{6}$ Department of Agronomy, Iowa State University, Ames, IA 50011, USA
}

Correspondence should be addressed to Bhalang Suriharn; sphala@kku.ac.th

Received 10 August 2020; Revised 2 November 2020; Accepted 6 November 2020; Published 19 November 2020

Academic Editor: Maria Serrano

Copyright (c) 2020 Supaporn Sukto et al. This is an open access article distributed under the Creative Commons Attribution License, which permits unrestricted use, distribution, and reproduction in any medium, provided the original work is properly cited.

\begin{abstract}
Waxy corn is a popular, alternative staple food in most Asian countries including Thailand. The availability of small-ear waxy corn genotypes with prolific ears and a high level of carotenoids is expected to benefit growers and consumers. Integrated evaluation among source germplasm is essential before performing further breeding efforts for enhancing prolific ears and high-carotenoid content. Thus, the present study explored the variability of ear prolificacy, total carotenoids, lutein, zeaxanthin, and beta-carotene among yellow smallear waxy corn accessions. About 44 corn accessions and 4 check varieties were evaluated for agronomic traits and yield components under multienvironment trials in a randomized complete block design (RCBD). The immature seed sample of these genotypes was analyzed to quantify the content of total carotenoids and some carotenoid fractions. All traits showed that low GXE interaction and significant genotypic diversity existed among all tested accessions with the predominant contribution of genotype to total phenotypic variation and beta-carotene. Accessions were clustered into four major groups based on the similarity of multiple carotenoids profiles. Three selected accessions (UT121001, KKU-WX112087, and KKU-WX212001) had higher values of total carotenoids, lutein, zeaxanthin, and beta-carotene than those of all check varieties. High and positive correlations among second-emerged ears, marketable second-emerged ears, and total ear number indicate that a higher chance of secondary ears becomes marketable ears with an increase of total ears per plant per hectare. Lutein and zeaxanthin had positive, strong correlations with total carotenoids. The implications and breeding strategies are discussed prior to promoting yellow small-ear waxy corn as a biofortified crop.
\end{abstract}

\section{Introduction}

Carotenoids are of interest to human health. Consequently, their consumption is correlated with safeguard from numerous chronic diseases, such as reducing the risk of cancer, cardiovascular diseases, and night blindness [1]. Carotenoids are plant pigments that normally can be found in plants, fruits, and vegetables accounting for red, orange, and yellow pigmentations [2]. They consist of two major groups, namely, xanthophylls (lutein, zeaxanthin, and $\beta$-cryptoxanthin) and carotene $(\beta$-carotene and $\alpha$-carotene) [3]. The major fractions lutein and zeaxanthin are largely found in corn kernels [4] and play a primary role in human health associated with eyes [5], especially as antioxidants or blue light filters that can protect ocular tissues from phototoxic damage [6]. Thus, corn is a good source of non-provitamin A carotenoids with lutein and zeaxanthin as major components [7]. 
Waxy corn (Zea mays L. var. ceratina) is popular and is commonly consumed in most Asian countries particularly China, Korea, Laos, Myanmar, Thailand, and Vietnam [8]. In Northeastern Thailand, people enjoy cooked fresh waxy corn as an alternative staple food to rice. Its unique texture and sticky kernels due to high amylopectin content [9] appeal to consumers. The kernel coloration of fresh waxy corn is normally either white or bicolor purple and white, with a poor expression of carotenoids including lutein and zeaxanthin [10]. Since the presence of orange corn kernels positively correlates with higher carotenoid concentrations and is a heritable trait [11], exploring corn accessions that possess a significant content of carotenoids is possible. Moreover, promoting small-ear waxy corn as a biofortified crop is promising because the carotenoid contents especially lutein and zeaxanthin are increased after steaming [12], and consumer acceptability of provitamin A biofortified maize in South Africa is high [13]. The content of carotenoids is quantitative traits controlled by a few major genes [14]. While additive gene effects are important for lutein, zeaxanthin, and beta-cryptoxanthin, nonadditive effects are predominant for beta-carotene and provitamin A [14].

In Thailand, waxy corn is consumed fresh and commonly paid for on a per ear basis instead of the kernel weight. Thus, waxy corn with prolific ears will benefit growers by boosting their incomes. Criteria of prolificacy are at least two marketable ears per plant and short period for ear emergence of both ears. Small-ear waxy corn is one of the prolific waxy corn races, plants with a smaller ear size because there is a close correlation between ear number per plant and marketable yield [15]. Since ear prolificacy is heritable and is controlled by additive gene effects [16], improvement of prolificacy through mass selection has been reported [15].

One of the keys to success in breeding programs is sufficiently diverse germplasm. Evaluation of germplasm is the first step in population improvement to produce promising lines with favorable traits. Previous evaluation of germplasm for phytochemical attributes has been conducted, namely, for lutein, zeaxanthin, and beta-cryptoxanthin [17] in field corn and anthocyanin content in purple waxy corn [18]. Screening for both ear prolificacy and several fractions of carotenoids in small-ear waxy corn has not yet been reported. This study aimed to explore the variability of ear prolificacy, total carotenoids, lutein, zeaxanthin, and beta-carotene among yellow small-ear waxy corn accessions. This information will be useful in a practical breeding program that emphasizes increased carotenoid levels and prolificacy in small-ear waxy corn.

\section{Materials and Methods}

2.1. Plant Materials. Forty-four small-ear waxy corn accessions were used in this study (Table 1). These accessions possess a wide range of kernel coloration from light yellow to dark orange. These materials originated from Thailand and other Asian countries and were collected by Chai Nat Field Crops Research Center, Department of Agriculture, Thailand, and Plant Breeding Research Center for Sustainable Agriculture of Khon Kaen University, Thailand.
2.2. Field Experiment. Forty-four accessions and four commercial small-ear waxy corn varieties (Tein Leang Khon Kaen, Tien Lai-52, Tien Salabsai, Tien Khaow) were subjected to randomized complete block design (RCBD) with three replications under field conditions. In total, there were 144 plots with a plot size of two rows that were $5.0 \mathrm{~m}$ long with a spacing of $0.8 \mathrm{~m}$ between rows and $0.25 \mathrm{~m}$ between plants to produce 40 plants per plot.

These genotypes were evaluated at two locations and two seasons in Thailand, namely, Uthai Thani Agricultural Research and Development Center, Uthai Thani province (UT) $\left(15^{\circ} 24^{\prime} 30.3^{\prime \prime} \mathrm{N}, 99^{\circ} 42^{\prime} 50.1^{\prime \prime} \mathrm{E} ; 84 \mathrm{~m}\right.$ above sea level (masl)), and Field Crop Research Station, Khon Kaen University, Khon Kaen province (KK) $\left(16^{\circ} 28^{\prime} 27.7^{\prime \prime} \mathrm{N}, 102 \circ 48^{\prime} 36.5^{\prime \prime} \mathrm{E}\right.$; $190 \mathrm{masl}$ ) in the dry season $2018 / 2019$ (rainfall rate: $68.0 \mathrm{~mm}$ (UT) and $98.5 \mathrm{~mm}(\mathrm{KK})$; minimum air temperature: $22.9 \mathrm{oC}$ (UT) and $20.4 \mathrm{oC}(\mathrm{KK})$; maximum air temperature: $33.7 \mathrm{oC}$ (UT) and $32.6 \mathrm{oC}(\mathrm{KK})$; relative humidity: 73\% (UT and KK) and rainy season 2019 (rainfall rate: $590 \mathrm{~mm}$ (UT) and $695 \mathrm{~mm}(\mathrm{KK})$; minimum air temperature: $25.6 \mathrm{oC}$ (UT) and $24.7 \mathrm{oC}(\mathrm{KK})$; maximum air temperature: $34.3 \mathrm{oC}(\mathrm{UT})$ and $33.6 \mathrm{oC}(\mathrm{KK})$; relative humidity: $75.2 \%$ (UT) and $76.6 \%$ (KK).

Tillage was done three times with an additional application of 3.125 tons per hectare organic manure. Corn seed was planted 2 seeds per hill and thinned to 1 plant per hill at two weeks after sowing (WAS). Fertilizer formula 15-15-15 of NPK was applied at the rate of $312.5 \mathrm{~kg}$ per hectare before planting and fertilizer formula $46-0-0$ at the rate of $125 \mathrm{~kg}$ per hectare was applied at three WAS. Corn ears were manually harvested at the fresh stage approximately 20 days after pollination (DAP) for yields and further phytochemicals analysis.

2.3. Phenotypic Data Collection. The following list of phenotypic data was recorded for whole environment trials (two locations and two seasons) such as anthesis day (days after sowing/DAS) as the number of days from sowing to the time when $50 \%$ of the plants in a plot shed pollen and ear height $(\mathrm{cm})$ as the distance from ground level to the node bearing the uppermost ear after milk stage. Both plant and ear heights were observed after the reproductive stage based on sample data of 10 random plants per plot.

Ear yields and yield components were measured at the milk stage approximately 20 DAP. The first DAP was counted when silks were at least $1 \mathrm{~cm}$ emerged. Ear yields were partitioned into first-emerged ear yield (ton ha ${ }^{-1}$ ), second-emerged ear yield (ton ha ${ }^{-1}$ ), and third-emerged ear yield (ton ha ${ }^{-1}$ ), measured in both unhusked and husked conditions. Ear numbers were recorded separately for $1^{\text {st }}, 2^{\text {nd }}$, and $3^{\text {rd }}$ ear emerged per plant and were converted to ears per hectare. The total ear yield was derived by adding the ear yield of each emerged ear $\left(1^{\text {st }}\right.$, $2^{\text {nd }}$, and $\left.3^{\text {rd }}\right)$. Yield components were measured on husked ear diameter $(\mathrm{cm})$ by HACHI digital caliper $0-150 \mathrm{~mm}$ and husked ear length $(\mathrm{cm})$ by Electronic Compact Digital Kitchen SF-400 A, based on ten representative ears per plot. 
TABLE 1: Small-ear waxy corn accessions used in this study.

\begin{tabular}{|c|c|c|c|c|c|}
\hline${ }^{\mathrm{a}}$ No. & Code & Accessions & ${ }^{\mathrm{b}}$ No. & Code & Accessions \\
\hline 1 & UT121001 & Tein Si Thong 54-1-5 & 25 & KKU-WX221041 & No.29(T38) \\
\hline 2 & UT121002 & Tak Ngai H3(S)-15-B & 26 & KKU-WX221057 & No.31(T40) \\
\hline 3 & KKU-WX112085 & CNW9702BC1(S)38-\#-B-4-B & 27 & KKU-WX221059 & No.7(T41) \\
\hline 4 & KKU-WX112086 & CNW9702BC1(S)40-\#-B-1-B & 28 & KKU-WX211004 & Mung Leang Phisanulok \\
\hline 5 & KKU-WX112087 & GD49SKF2 & 29 & KKU-WX211012 & Tein Ayutaya \\
\hline 6 & KKU-WX112088 & Tein Yellow (Wichai) (W64) & 30 & KKU-WX211013 & Tein Leang Nakorn Sawan \\
\hline 7 & KKU-WX112089 & Tein Yellow (Wichai) (W65) & 31 & KKU-WX211014 & Tein Ban Kao \\
\hline 8 & KKU-WX112109 & Tein Fancy (Wichai) & 32 & KKU-WX211015 & Tein Leang Udon Thani \\
\hline 9 & KKU-WX122018 & Miang Yang Gia Coi & 33 & KKU-WX211016 & Tein Leang Phisanulok \\
\hline 10 & KKU-WX111028 & Kaow Neaw Sri That Leang & 34 & KKU-WX211017 & Saloi Nakhorn Phanom \\
\hline 11 & KKU-WX111036 & $\mathrm{Mu}$ Ser & 35 & KKU-WX211018 & Tein Nong Bhau Leang \\
\hline 12 & KKU-WX112092 & GC.Krabngoo. Nakorn Sawan & 36 & KKU-WX211019 & Tein Leang Tra Peon Yai \\
\hline 13 & KKU-WX211020 & Tein Leang Nam Wang & 37 & KKU-WX221043 & No.30(T93) \\
\hline 14 & KKU-WX211021 & Tein Nong Sam Rong Udon Thani & 38 & KKU-WX221036 & GC. Saleetien No.11 Chiang Mai \\
\hline 15 & KKU-WX211022 & Tein Rom Phan Nam Nan & 39 & KKU-WX221038 & Tein NaKorn Sawan \\
\hline 16 & KKU-WX211023 & Tein Sai Nam Pheong & 40 & KKU-WX221039 & GC.Teinluang. Nakonsawan \\
\hline 17 & KKU-WX212001 & Tein Leang Pean Maong & 41 & KKU-WX221040 & GC.Tein. No.29. Tak \\
\hline 18 & KKU-WX221045 & Tein Yellow (T13) & 42 & KKU-WX221042 & GC.Tein. No.30. Tak \\
\hline 19 & KKU-WX221046 & CNW9702BC1(S)36-\#-B-1-B & 43 & KKU-WX221044 & GC.Nipibangka.Chachoengsao \\
\hline 20 & KKU-WX221047 & CNW9702BC1(S)36-\#-B-2-B & 44 & KKU-WX221054 & GC.Tein.No.8. Chiang Mai \\
\hline 21 & KKU-WX221048 & CNW9702BC1(S)36-\#-B-5-B & 45 & Check1 & Tein Leang Khon Kaen \\
\hline 22 & KKU-WX221049 & CNW9702BC1(S)46-\#-B-B & 46 & Check2 & Tein Lai-52 \\
\hline 23 & KKU-WX221052 & Nimitr Bankla & 47 & Check3 & Tein Salabsai \\
\hline 24 & KKU-WX221037 & No.11(T37) & 48 & Check 4 & Tein Khaow \\
\hline
\end{tabular}

${ }^{\mathrm{a} A c c e s s i o n}$ numbers 1 to 24 are on the left three columns. ${ }^{\mathrm{b}}$ Accession numbers 25 to 48 are on the right three columns.

2.4. Sample Preparation, Extraction, and Phytochemical Analysis. Corn samples derived from a two-season trial at Field Crop Research Station, Khon Kaen University, Khon Kaen, were extracted and analyzed. Details of the analytical procedures are given hereinafter.

2.4.1. Sample Preparation. Ten ears of each plot were manually harvested 20 DAP. These samples were derived from sibling hand pollination to ensure genetic purity. Only undamaged kernels in the middle part of the ears were kept and were packed in a sealed plastic bag as a plot sample. Then, the packed samples were dipped in liquid nitrogen for $1 \mathrm{~min}$ and were stored at $-20^{\circ} \mathrm{C}$ until the day of phytochemical analysis to avoid kernel oxidation and decay.

2.4.2. Carotenoid Extraction. Carotenoid extraction followed Schaub et al. [19] with adjustments. One gram of fresh corn kernels was crushed and loaded into a test tube. Then, $6 \mathrm{~mL}$ ethanol and 1-2 flakes of $0.1 \mathrm{w} / \mathrm{v}$ Butylated Hydroxyl Toluene (BHT) were added before shaking with a vortex mixer. Samples were heated in hot water at $85^{\circ} \mathrm{C}$ for $3 \mathrm{~min}$ and then shaken, and the process was repeated twice. Saponification was performed by adding $120 \mu \mathrm{L}$ of $80 \%$ https:// pubchem.ncbi.nlm.nih.gov/compound/

potassium_hydroxide $\mathrm{KOH}$ and shaking gently by hand. Then, the samples were heated in hot water at $85^{\circ} \mathrm{C}$ for $5 \mathrm{~min}$ and shaken, and this procedure was repeated twice. Samples were placed in ice for $5 \mathrm{~min}$ and added $4 \mathrm{~mL}$ of distilled water. Samples were then mixed thoroughly by the vortex mixer. $3 \mathrm{~mL}$ of petroleum ether (PE): diethyl ether (DE) ratio 2:1 was added and shaken well until two layers were separated. The aqueous layer was loaded into a new test tube. This solvent fractionation process was repeated twice, and the resulting layers were pooled. After that, the volume was adjusted to $10 \mathrm{~mL}$ with $\mathrm{PE}: \mathrm{DE}$. The carotenoid extract was divided equally into two parts for different purposes. One fraction was used to determine the total carotenoid concentration of each genotype. Absorbance was measured by spectrophotometer at $450 \mathrm{~nm}$ wavelength for determination of total carotenoid concentration following this formula [20]:

$$
\text { total carotenoid }\left(\mu \mathrm{g} \cdot \mathrm{g}^{-1} \mathrm{FW}\right)=\frac{A \times V \times 10^{4}}{2500 \times W},
$$

where $A$ is the light absorbance, $V$ is the sample volume, and $W$ is the sample weight.

The $2^{\text {nd }}$ fraction was used to quantify the concentration of lutein, zeaxanthin, and beta-carotene. The extracts were evaporated with a stream of nitrogen gas and covered with aluminum foil to prevent exposure to light. Then, samples were stored at $-20^{\circ} \mathrm{C}$ until further analysis by high-performance liquid chromatography (HPLC).

2.4.3. Analysis of Carotenoids by HPLC-DAD. Frozen carotenoid extracts were dissolved with $1 \mathrm{~mL}$ of methyl tertbutyl ether (MTBE): methanol $(75: 25)$ and passed through a $0.45 \mu \mathrm{M}$ filter. $20 \mu \mathrm{L}$ of the extracts was injected into HPLC according to Gupta et al. [20] by using a YMC C30 column $(5 \mu \mathrm{M}, 4.6 \times 250 \mathrm{mM})$, coupled with $\mathrm{C} 18$ guard column. The analysis was performed on an HPLC system (Shimadzu, Kyoto, Japan) equipped with LC-20AD pumps, a SIL-20AC autosampler, and an SPD-M20 A photodiode array detector. 
The carotenoids were separated at a flow rate of $1 \mathrm{~mL} \mathrm{~min}^{-1}$ and with a gradient mobile phase elution composed of (A) methanol: deionized water (98:2 v/v), (B) methanol: deionized water $(95: 5 \mathrm{v} / \mathrm{v})$, and (C) MTBE. The gradient started at 0 min with mobile phase A : C $(80: 20)$, and the concentrations were changed linearly for two minutes to A : C $(60: 40)$ with a flow rate of $1.40 \mathrm{~mL} \mathrm{~min}^{-1}$. After $2 \mathrm{~min}$, the flow rate was changed to $1.00 \mathrm{~mL} \mathrm{~min}^{-1}$, followed by a change in concentration to B:C $(60: 40)$ for $12 \mathrm{~min}$; then, the concentration was changed to $\mathrm{B}(100)$ and after $1 \mathrm{~min}$ was changed to A:C $(60: 40)$ for $7 \mathrm{~min}$. The concentration of $20 \mu \mathrm{L}$ of samples was determined by calculating the area under the peaks of carotenoids compared with that of standard carotenoid solutions at $25^{\circ} \mathrm{C}$ [21].

2.4.4. Preparation of Standard Carotenoids. Stock standard solutions of lutein (CaroteNature, Switzerland), zeaxanthin (CaroteNature, Switzerland), and beta-carotene (SigmaAldrich, USA) were prepared with ethanol (HPLC grade) and then adjusted to a volume of $10 \mathrm{~mL}$. Standard concentrations were determined by measuring the absorbance with the UV/Vis spectrum at 445, 450, and $450 \mathrm{~nm}$ for lutein, zeaxanthin, and beta-carotene, respectively. Thus, the concentration was calculated by the Beer-Lambert Law [21].

$$
A=\varepsilon \cdot C \cdot I,
$$

where $C$ is the solution concentration $\left(\mathrm{g} \mathrm{mL}^{-1}\right), A$ is the absorbance value, $I$ is the distance of the light shining through the sample $(\mathrm{cm})$ (in this case, $I=1$ ), and $\varepsilon$ is the absorption coefficient defined as $A_{1 \mathrm{~cm}}^{1 \%}$ in which $A_{1 \mathrm{~cm}}^{1 \%}$ of lutein in ethanol is 2550, zeaxanthin in ethanol is 2480, and beta-carotene in ethanol is 2592 .

2.4.5. Data Analysis. The error variances of each environment were used for homogeneity tests. The combined ANOVA in RCBD [22] across two seasons and two locations was conducted for flowering traits, plant architecture, yield traits, and yield components. Phytochemical attributes were analyzed by combined ANOVA in RCBD of two-season data derived from Khon Kaen province trials only. Broad-sense heritability estimates were calculated using the following formula [23] by assuming genotype as a random effect and environment (location and season) as a fixed effect.

$$
\begin{aligned}
V_{\mathrm{GE}} & =\frac{\mathrm{MS}_{\mathrm{GE}}-\mathrm{MS}_{\text {Error }}}{r}, \\
V_{\mathrm{G}} & =\frac{\mathrm{MS}_{\mathrm{G}}-\mathrm{MS}_{\text {Error }}-r V_{\mathrm{GE}}}{\mathrm{re}}, \\
V_{\mathrm{P}} & =V_{\mathrm{G}}+V_{\text {Error }}, \\
h_{\mathrm{bs}}^{2} & =\frac{V_{\mathrm{G}}}{V_{\mathrm{P}}},
\end{aligned}
$$

where $V_{\mathrm{GE}}$ is the variance of $\mathrm{G} \times \mathrm{E}, \mathrm{MS}_{\mathrm{GE}}$ is the mean squares of $\mathrm{G} \times \mathrm{E}, \mathrm{MS}_{\mathrm{Error}}$ is the mean squares of error, $r$ is the number of replication, $V_{\mathrm{G}}$ is the genotypic variance, $\mathrm{MS}_{\mathrm{G}}$ is the mean squares of genotype, $e$ is the number of environment, $V_{\mathrm{P}}$ is the phenotypic variance, $V_{\text {Error }}$ is the variance of error, and $h_{\mathrm{bs}}^{2}$ is the broad-sense heritability.

The least significant differences (LSDs) were used to compare the genotype means at $p=0.05$. A dendrogram was constructed based on a two-way Ward's cluster analysis, derived from a data matrix of all observed traits among 48 genotypes. Pearson's linear correlation coefficients were calculated to estimate the relationship between targeted traits.

Several statistical programs were used for data analysis. Dendrograms were constructed by JMP Pro software [24]. Pearson's correlation analysis and both single and combined ANOVA were done using Statistix10 [25].

\section{Results and Discussion}

3.1. Variabilities in Yields, Yield Components, and Carotenoids. The influence of environments (E) was significant $(p=0.01)$ for all traits except unhusked yield (UY), husked yield (HY), and ear number at the first ear position $\left(E N^{1}\right)$ (Table 2). Genotypes $(G)$ were significantly different $(p=0.01)$ for all traits. Interactions between $\mathrm{G}$ and $\mathrm{E}$ $(\mathrm{G} \times \mathrm{E})$ were significant for all traits except for the number of marketable ears at the second ear position $\left(\mathrm{EN}^{2} \mathrm{M}\right)$, husked ear length (EL), and husked ear diameter (ED). Environment explained a large portion for EL $(172.8 * *)$, anthesis date (AD) $(594 * *)$, ear height $(\mathrm{EH})(41860 * *)$, and total carotenoids concentration (TC) $(243.5 * *)$. Genotypes predominantly contributed to a large portion for yield $(11.0 * *-44.9 * *)$ and some carotenoid fractions $(2.5 * *-23.2 * *)$. However, $\mathrm{GxE}$ displayed low contribution for UY and HY $(1.5 * *-6.9 * *)$, ear numbers (EN) $(2.6 * *-10.0 * *)$, and some carotenoid fractions $(0.3 * *-7.2 * *)$. Broad-sense heritability estimates of observed traits ranged from low (0.05) to high (0.98).

Genotype contributed to the largest proportion of total phenotypic variation for most traits and often exceeded the contribution of $\mathrm{G} \times \mathrm{E}$ interactions, suggesting that total yields, EN, and carotenoid content are selectable traits in small-ear waxy corn. This corroborates previous studies on grain yield and carotenoids in maize [17]. However, when the variance of ear number described by $\mathrm{G} \times \mathrm{E}$ is greater than all other terms in the model, because the contribution of the genotype to the total variance in $\mathrm{EN}$ was reduced, the effect of E was increased. In this study, heritability estimates of EN were relatively low. Even though the expression of ear prolificacy is qualitative, the inheritance of this trait is controlled by multiple genes and is prone to environmental effect [16]. For instance, the contribution of genotype to the total variance in EN was reduced while the effect of $\mathrm{E}$ was increased. A previous study in semiprolific corn reported that environmental conditions could determine the size and the number of second ears that were responsible for any increased yields [26]. Yields and EN are quantitative traits and have a polygenic inheritance, controlled by multiple minor genes. Therefore, minimizing experimental error under normal conditions with careful attention to selection will help breeders to identify true-to-type genotypes with high yield and prolific ears. Otherwise, the phenotypic value 
TABLE 2: Mean squares for yields, yield components, agronomic traits, and carotenoids of 48 small-ear waxy corn genotypes evaluated across four environments in Thailand between 2018 and 2019.

\begin{tabular}{|c|c|c|c|c|c|c|c|c|}
\hline $\begin{array}{l}\text { SOV } \\
\text { Df }\end{array}$ & & $\begin{array}{l}\text { Environment }(\mathrm{E}) \\
3\end{array}$ & $\begin{array}{c}\text { Replication } \\
8\end{array}$ & $\begin{array}{c}\text { Genotype }(\mathrm{G}) \\
47\end{array}$ & $\begin{array}{c}\mathrm{GxE} \\
141\end{array}$ & $\begin{array}{c}\text { Error } \\
376\end{array}$ & CV (\%) & $h_{\mathrm{bs}}^{2}$ \\
\hline \multirow{2}{*}{ UY } & $1^{\text {st }}$ & $77.5^{*}$ & 15.6 & $11.0^{* *}$ & $1.5^{* *}$ & 0.5 & 18.8 & 0.61 \\
\hline & Total & 99.2 & 36.4 & $14.3^{* *}$ & $2.2^{* *}$ & 0.7 & 17.6 & 0.59 \\
\hline \multirow{2}{*}{ HY } & $1^{\text {st }}$ & 56.3 & 36.1 & $36.2^{* *}$ & $4.9^{* *}$ & 2.3 & 21.7 & 0.53 \\
\hline & Total & 193.3 & 101.2 & $44.9^{* *}$ & $6.9^{* *}$ & 3.0 & 19.7 & 0.51 \\
\hline \multirow{4}{*}{ EN } & $1^{\text {st }}$ & 2.2 & 6.0 & $1.4^{* *}$ & $8.8^{* *}$ & 3.6 & 11.7 & 0.21 \\
\hline & $2^{\text {nd }}$ & $1.8^{* *}$ & 1.4 & $7.0^{* *}$ & $10.0^{* *}$ & 5.4 & 43.1 & 0.24 \\
\hline & $2^{\text {nd }} \mathrm{M}$ & $7.2^{* * *}$ & 4.8 & $4.2^{* *}$ & 6.7 & 3.5 & 61.7 & 0.36 \\
\hline & Total & $3.0^{* *}$ & 3.7 & $1.5^{* *}$ & $2.6^{* *}$ & 1.2 & 15.7 & 0.18 \\
\hline \multirow{2}{*}{ EL } & $1^{\text {st }}$ & $172.8^{* *}$ & 0.8 & $18.0^{* *}$ & 1.6 & 1.3 & 8.9 & 0.51 \\
\hline & $2^{\text {nd }}$ & $70.4^{* *}$ & 3.1 & $17^{* *}$ & 10.3 & 8.4 & 28.2 & 0.06 \\
\hline \multirow{2}{*}{ ED } & $1^{\text {st }}$ & $1.8^{* *}$ & 0.1 & $1.1^{* *}$ & 0.1 & 0.1 & 8.1 & 0.45 \\
\hline & $2^{\text {nd }}$ & $1.5^{* *}$ & 0.1 & $1.0^{* *}$ & 0.6 & 0.6 & 26.0 & 0.05 \\
\hline $\mathrm{AD}$ & & $594^{* *}$ & 13 & $114^{* *}$ & $7.3^{* *}$ & 4.4 & 4.4 & 0.67 \\
\hline $\mathrm{EH}$ & & $41,860^{* *}$ & 1,180 & $4,207^{* *}$ & $140^{* *}$ & 90.3 & 10.5 & 0.79 \\
\hline $\mathrm{L}^{\mathrm{a}}$ & & $34.5^{* *}$ & 0.9 & $2.5^{* *}$ & $0.6^{* *}$ & 0.01 & 12.1 & 0.97 \\
\hline $\mathrm{Z}^{\mathrm{a}}$ & & $65.3^{* *}$ & 0.4 & $8.0^{* *}$ & $1.4^{* *}$ & 0.1 & 16.2 & 0.92 \\
\hline $\mathrm{BC}^{\mathrm{a}}$ & & $4.0^{* *}$ & 0.0 & $0.0^{* *}$ & $0.3^{* *}$ & 0.0 & 11.2 & 0.98 \\
\hline $\mathrm{TC}^{\mathrm{a}}$ & & $243.5^{* *}$ & 9.0 & $23.2^{* *}$ & $7.2^{* *}$ & 0.9 & 19.3 & 0.75 \\
\hline
\end{tabular}

$h_{\mathrm{bs}}^{2}=$ broad-sense heritability estimates. UY (ton ha $\left.{ }^{-1}\right)=$ unhusked yield, $\mathrm{HY}\left(\mathrm{ton} \mathrm{ha}^{-1}\right)=$ husked yield, EN $\left(\mathrm{ear} \mathrm{ha}^{-1}\right)=$ ear number, EL $(\mathrm{cm})=$ husked ear length, $\mathrm{ED}(\mathrm{cm})=$ husked ear diameter, $\mathrm{AD}(\mathrm{DAS})=$ anthesis date, $\mathrm{EH}(\mathrm{cm})=$ ear height, $L\left(\mu \mathrm{g} \mathrm{g}^{-1} \mathrm{FW}\right)=$ lutein, $\mathrm{Z}\left(\mu \mathrm{g} \mathrm{g}^{-1} \mathrm{FW}\right)=$ zeaxanthin, $\mathrm{BC}\left(\mu \mathrm{g} \mathrm{g} \mathrm{g}^{-1} \mathrm{FW}\right)=$ betacarotene, TC $\left(\mu \mathrm{g} \mathrm{g}^{-1} \mathrm{FW}\right)=$ total carotenoids, $1^{\text {st }}=$ the first ear position, $2^{\text {nd }}=$ the second ear position, $2^{\text {nd }} M=$ the number of marketable ears at the second ear position. ${ }^{a}$ Data derived from Khon Kaen province across two seasons. * Significant at $p=0.05$ and ${ }^{* *}$ significant at $p=0.01$, respectively.

of a genotype will be overestimated or underestimated, misleading breeders in germplasm selection [27].

In this study, both total carotenoids and the fractions lutein $(\mathrm{L})$, zeaxanthin $(\mathrm{Z})$, and beta-carotene $(\mathrm{BC})$ had minor environmental effects, and carotenoid fractions showed small but significant $\mathrm{G} \times \mathrm{E}$ interactions. This finding corroborated previous reports on carotenoid content among tropical-adapted yellow maize inbreds [28] and $\mathrm{F}_{1}$ maize hybrids [4]. Thus, most tested genotypes could maintain the level of carotenoids across seasons in typical tropical conditions of Thailand. Maize growers selected the best ears to maintain the germplasm. This finding is helpful for increasing variation of carotenoid germplasm; it makes it beneficial and easier for genotype improvement for both maize growers and breeders. Since small-ear waxy corn is a cash crop, growers can optimize the cropping index up to three times per year. Likewise, the low $G \times E$ is desirable for breeders as they can carry out routine selections up to three cycles per year to obtain earlier high-carotenoid maize inbreds. In addition, genotype was the main source of variation in total carotenoids (TC), L, and $\mathrm{Z}$. The result of our studies corroborated a previous investigation on similar traits in provitamin A biofortified maize [29]. Both high genotypic variation and broad-sense heritability estimates in carotenoids suggest that these traits are highly heritable, and selection on these traits could be performed at the early generation of population improvement. A comparative study revealed high heritability estimates (68\% to $80 \%$ ) for TC, L, and Z in Chinese maize germplasm [30]. Thus, phenotypic selection for these attributes seems feasible.
3.2. Alteration of Prolificacy, Total Yields, and Carotenoids Affected by Different Environments. The tested corn accessions showed the highest prolificacy regarding ear number at the first position $\left(\mathrm{EN}^{1}\right)$, ear number at the second position $\left(\mathrm{EN}^{2}\right)$, marketable ear number at the second position $\left(\mathrm{EN}^{2} \mathrm{M}\right)$, and total ear number (TEN) at Khon Kaen experimental site in the rainy season $(52,858 ; 32,366 ; 19,566$; 88,387 ears $\mathrm{ha}^{-1}$, respectively), compared to other environments (Table 3). However, a significant reduction of ear number affected by different environments was noticed for $\mathrm{EN}^{2}\left(32,366\right.$ to 7,086 ears ha $\left.{ }^{-1}\right)$ and $\mathrm{EN}^{2} \mathrm{M}(19,566$ to 3,943 ears $\mathrm{ha}^{-1}$ ) leading to a reduction in TEN (88,387 to 57,007 ears $\left.\mathrm{ha}^{-1}\right)$. In contrast, different environments slightly altered both total unhusked yield (5.1 to 3.6 tons $\mathrm{ha}^{-1}$ ) and total husked yield ( 9.7 to 7.6 tons $\mathrm{ha}^{-1}$ ).

In this study, season showed larger effects than the location in altering EN and UY because our accessions were more prolific and had better yields in the rainy season tested either in Khon Kaen (KK) or Uthai Thani (UT). In parallel, our weather data showed that average relative humidity and daily temperatures (both minimum and maximum) in the rainy season were higher than those in the dry season. In comparison to a field corn study, favorable growing conditions such as available soil moisture, longer daily solar radiation, and higher temperature without exceeding maximum threshold could promote ear prolificacy and grain yield [31]. Since heat will affect maize pollen development during the period between ear differentiation and ear emergence [32], these factors became more critical of seed production causing a grain filling lag phase [33]. Further, less impact of contrasting environments was noticed on both $\mathrm{EN}^{1}$ and $\mathrm{HY}$ of the first ear. These findings agree with a 
TABLE 3: Overall genotype means for yields, yield components, and agronomic characters of 48 small-ear waxy corn genotypes in four environments (location-season combinations) in Thailand between 2018 and 2019.

\begin{tabular}{|c|c|c|c|c|c|}
\hline Parameters & & KKR & UTR & KKD & UTD \\
\hline \multirow{2}{*}{ UY (tons ha ${ }^{-1}$ ) } & $1^{\text {st }}$ & 6.7 & 7.8 & 6.3 & 7.1 \\
\hline & Total & 9.7 & 9.7 & 7.6 & 7.9 \\
\hline \multirow{2}{*}{ HY (tons ha ${ }^{-1}$ ) } & $1^{\text {st }}$ & $3.6 \mathrm{ab}$ & $4.4 \mathrm{a}$ & $3.0 \mathrm{~b}$ & $4.5 \mathrm{a}$ \\
\hline & Total & $5.1 \mathrm{a}$ & $5.4 \mathrm{a}$ & $3.6 \mathrm{~b}$ & $5.0 \mathrm{ab}$ \\
\hline \multirow{4}{*}{ EN $\left(\right.$ ears ha $\left.{ }^{-1}\right)$} & $1^{\text {st }}$ & $52,858 \mathrm{a}$ & $53,974 a$ & $45,494 b$ & $52,496 a$ \\
\hline & $2^{\text {nd }}$ & $32,366 a$ & $17,485 b$ & $10,981 b c$ & $7,086 c$ \\
\hline & $2^{\text {nd }} \mathrm{M}$ & $19,566 \mathrm{a}$ & $9,776 b$ & $5,307 \mathrm{bc}$ & $3,943 c$ \\
\hline & Total & $88,387 a$ & $72,030 \mathrm{~b}$ & $57,007 \mathrm{bc}$ & $59,640 c$ \\
\hline AD (day) & & $46.4 c$ & $49.8 \mathrm{a}$ & 48.1b & $45.1 \mathrm{~d}$ \\
\hline $\mathrm{EH}(\mathrm{cm})$ & & $84.5 c$ & $94.1 \mathrm{~b}$ & $72.3 d$ & $112.7 \mathrm{a}$ \\
\hline \multirow{2}{*}{$\mathrm{EL}(\mathrm{cm})$} & $1^{\text {st }}$ & $12.6 \mathrm{c}$ & $13.6 \mathrm{~b}$ & $11.5 \mathrm{~d}$ & $13.9 \mathrm{a}$ \\
\hline & $2^{\text {nd }}$ & $10.7 \mathrm{a}$ & $10.8 \mathrm{a}$ & $9.3 \mathrm{~b}$ & $10.5 \mathrm{a}$ \\
\hline \multirow{2}{*}{$\mathrm{ED}(\mathrm{cm})$} & $1^{\text {st }}$ & $3.3 c$ & $3.4 \mathrm{~b}$ & $3.4 \mathrm{~b}$ & $3.5 \mathrm{a}$ \\
\hline & $2^{\text {nd }}$ & $3.0 \mathrm{ab}$ & $3.1 \mathrm{a}$ & $2.9 \mathrm{~b}$ & $2.8 \mathrm{c}$ \\
\hline
\end{tabular}

$\mathrm{UY}=$ unhusked yield, $\mathrm{HY}=$ husked yield, $\mathrm{EN}=$ ear number, $\mathrm{AD}=$ anthesis date, $\mathrm{EH}=$ ear height, $\mathrm{EL}=$ husked ear length, $\mathrm{ED}=$ husked ear diameter, $1^{\mathrm{ST}}=$ the first ear position, $2^{\text {nd }}=$ the second ear position, $2^{\text {nd }} M=$ the number of the marketable ear at the second ear position. KKR $=$ at Khon Kaen in the rainy season 2019, UTR = at Uthai Thani in the rainy season 2019, KKD = at Khon Kaen in the dry season 2018/2019, UTD = at Uthai Thani in the dry season 2018/2019. Means followed by different letters within the same row are significantly different based on LSD at $p=0.05$.

previous investigation in semiprolific corn [26], suggesting that the first ear yield is relatively stable and any differences in total yield are mainly due to the degree of development of the second ear.

Although environmental effects contributed to a minor percentage (less than 20\%) of the total variation in carotenoids (Table 2), further analyses of this effect may be important. Carotenoid content of grain produced in the rainy season had significantly higher levels of all fractions of carotenoids (Figure 1). The fresh samples of all accessions grown in the rainy season had TC, L, Z, and BC more than twice those in the dry season ( 3.86 to $5.70 \mu \mathrm{g} \mathrm{g}^{-1} \mathrm{FW}, 0.76$ to $1.43 \mu \mathrm{gg}^{-1} \mathrm{FW}, 1.32$ to $2.24 \mu \mathrm{gg}^{-1} \mathrm{FW}$, and 0.35 to $0.59 \mu \mathrm{gg}^{-1} \mathrm{FW}$, respectively). These results confirmed a similar report in field corn [28]. The rainy season provided a more suitable growing condition for plants compared to the dry season such as sufficient water, sunlight, temperature, and humidity, facilitating increased photosynthesis. Thus, the plants grown during the rainy season had more plastids including chloroplasts and chromoplasts for carotenoid biosynthesis than those grown during the dry season [34].

3.3. Cluster Analysis. A dendrogram based on carotenoid concentration (CT), TC, L, Z, and BC classified 48 small-ear waxy corn genotypes into four major groups (A-D) (Figure 2). Group A was the smallest group consisting of five genotypes, namely, UT121001, KKU-WX112087, KKUWX212001, KKU-WX211018, and KKU-WX221040 having the highest contents of TC, L, Z, and BC $\left(0.36-18.11 \mu \mathrm{gg}^{-1}\right.$ FW) (Table 4). Most of them had higher contents of $\mathrm{Z}$ and TC (2.78-18.11 $\mathrm{gg} \mathrm{g}^{-1} \mathrm{FW}$ ) (Table 4), and they had high contents of $\mathrm{L}$ and BC except for KKU-WX221040 (0.37-3.08 $\mu \mathrm{g} \mathrm{g}^{-1} \mathrm{FW}$ ) (Table 4) demonstrating the intermediate value of BC. While group B was the largest group consisting of 22 genotypes, most maize genotypes comprising this group had low to medium values of $\mathrm{L}, \mathrm{Z}, \mathrm{BC}$, and
TC, and all members in this group excluding Check 4 had the lowest values of L, Z, BC, and TC. Among genotypes comprising this group, Check 4 showed the lowest values of L, Z, TC, and a low value of BC. Group C consisted of six genotypes, and all members in this group had medium values of $\mathrm{L}$ and $\mathrm{TC}$, a low to medium value of $\mathrm{Z}$, and a medium to high value of BC. Group D contained 15 genotypes and all genotypes in this group showed a significant range from low to high values of $\mathrm{L}$. These genotypes had a medium to high value of $\mathrm{Z}$, a low to medium value of $\mathrm{BC}$, and a medium value of TC.

The carotenoid profiles of the top five corn genotypes (Figure 3) derived from the cluster analysis (Figure 2) are presented in Table 4. This result suggested that the utilization of genotype clustering by considering other important traits including prolific ear and yield could classify all accessions into four major groups. The first group had a high yield and the highest $\mathrm{L}$ (3.20 and $\left.1.40 \mu \mathrm{gg}^{-1} \mathrm{FW}\right)$ and $\mathrm{Z}$ (7.26 and $\left.2.88 \mu \mathrm{gg}^{-1} \mathrm{FW}\right)$ concentrations were found in KKUWX112087. In contrast, it has a low number of prolific ears. The second group included UT121001 with the highest level of L (4.58 and $2.58 \mu \mathrm{g} \mathrm{g}^{-1} \mathrm{FW}$ ) and Z (4.90 and $2.78 \mu \mathrm{g} \mathrm{g}^{-1}$ FW), but it possessed low yield and poor prolific ears. The third group included KKU-WX212001, KKU-WX211018, and KKU-WX221040 with high levels of $\mathrm{L}\left(0.90-3.08 \mu \mathrm{g} \mathrm{g}^{-1}\right.$ FW) and $\mathrm{Z}\left(2.31-5.03 \mu \mathrm{g} \mathrm{g}^{-1} \mathrm{FW}\right)$, and these accessions had moderate yield and prolific ears. The last group included all check varieties with high yield and prolific ear, but poor CT. The highest content was observed in KKU-WX112087 and KKU-WX212001 (5.03 and $\left.3.60 \mu \mathrm{g} \mathrm{g}^{-1} \mathrm{FW}\right)$.

The relationships between TC and the carotenoids fractions (L, Z, and BC) were revealed in this study (Table 5). $\mathrm{L}$ and $\mathrm{Z}$ were strongly correlated with TC ( $r=0.69$ and 0.81 , respectively). Thus, $\mathrm{L}$ and $\mathrm{Z}$ were two major factions of TC in small-ear waxy corn genotypes. In comparison to previous reports, L contributed to 18 to $40 \%$ of the TC content, whereas $\mathrm{Z}$ accounted for 40 to $75 \%$ of TC of dried kernels 


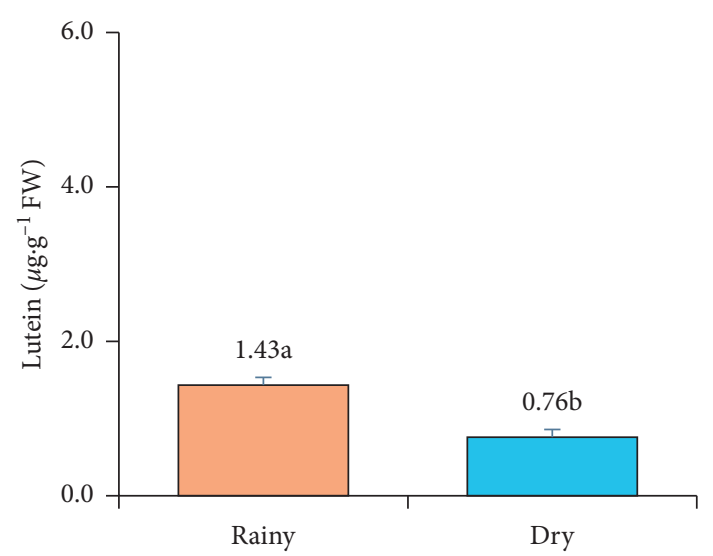

(a)

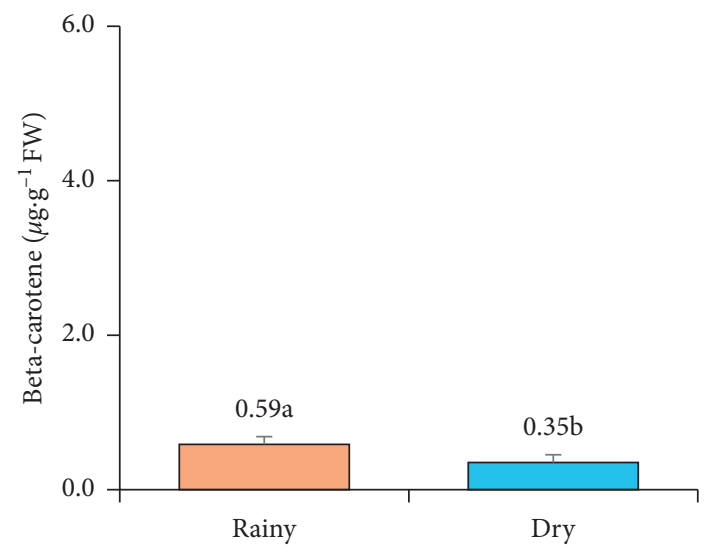

(c)

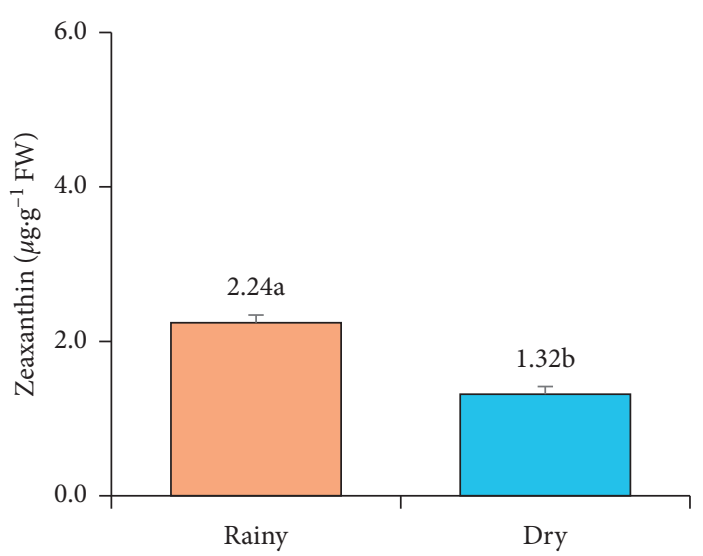

(b)

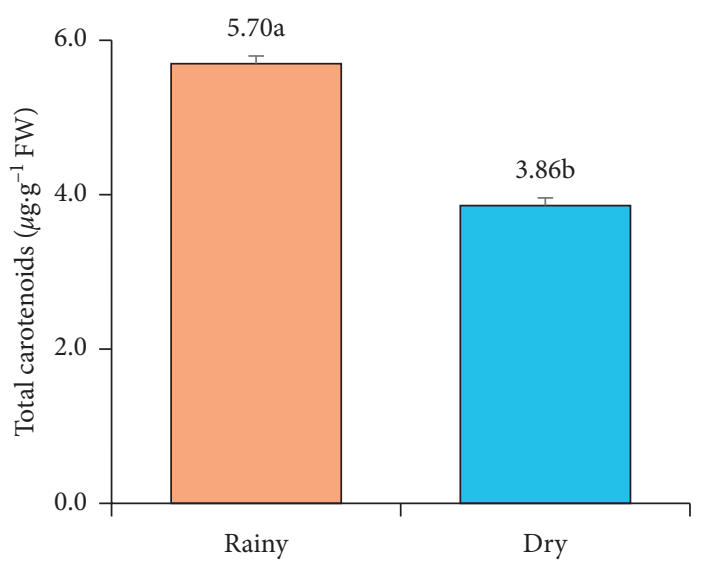

(d)

FIGURE 1: Seasonal effect on the grand means of 48 small-ear waxy corn genotypes for (a) lutein content, (b) zeaxanthin content, (c) betacarotene content, and (d) total carotenoids content evaluated in the dry season 2018/2019 and rainy season 2019 in Khon Kaen. Means followed by different letters across bars are significantly different based on LSD at $p=0.05$.

among field corn inbreds and hybrids $[28,35]$. This study revealed that $\mathrm{L}$ and $\mathrm{Z}$ were also major carotenoid fractions in immature kernels. BC did not significantly relate to TC $(r=0.21) . \mathrm{BC}$ is one of the intermediates (provitamin A), whereas $\mathrm{L}$ and $\mathrm{Z}$ are the terminal product (non-provitamin A) in the carotenoid biosynthesis pathway [36]. Positive, high linear correlations between TC and the two fractions ( $\mathrm{L}$ and $\mathrm{Z}$ ) are desired since any increase in the fractions would increase the total carotenoid concentration. TC could be used for indirect selection in breeding programs for nonprovitamin A carotenoids ( $\mathrm{L}$ and $\mathrm{Z}$ ).

Positive, close linear correlations between TC and the two fractions $\mathrm{L}$ and $\mathrm{Z}$ are desirable since any increase in the fractions would increase the TC content. TC could be used for indirect selection in breeding programs to non-provitamin A carotenoids ( $\mathrm{L}$ and $\mathrm{Z}$ ). The use of a spectrophotometer to quantify TC is relatively cost- and timesaving, compared to the use of HPLC for carotenoids profiling.

Direct value comparison of similar carotenoid fractions of fresh yellow waxy corn is unavailable. However, these values were still lower than those reported in dried kernels of provitamin A biofortified maize hybrids [35] and tropical- adapted yellow maize inbred lines [28]. These differences are understandable because mature kernels experience an increase in the accumulation of dry matter and a decrease in moisture content. The concentrations of $\mathrm{L}, \mathrm{Z}$, and $\mathrm{BC}$ in field corn and sweet corn were increased significantly as the harvesting time was delayed from the milking stage to physiological maturity $[37,38]$.

Linear correlation analysis among fourteen traits is presented in Figure 4. The $\mathrm{EN}^{1}$ showed positive and medium correlation coefficients with the $\mathrm{EN}^{2}(r=0.52)$ and the $\mathrm{EN}^{2} \mathrm{M}$ $(r=0.48)$. The $\mathrm{EN}^{2} \mathrm{M}$ was closely correlated with the TEN $(r=0.95)$. The TEN had medium to high correlation coefficients with TUY $(r=0.67)$ and THY $(r=0.67)$. Hence, ear number per plant had a moderate correlation with total yields, as some accession had a large size of the first ear which is larger than the second ear, as it is sometimes necessary to harvest only the first ear. However, some accession had the same size for the first and second ears, both traits moderate to high compared to other accessions. Thus, it is reliable to assign prolific ear traits as indirect selection to total yields. Prolificacy illustrates the reproductive plasticity of semiprolific ears in response to different environments and plant densities [39]. 


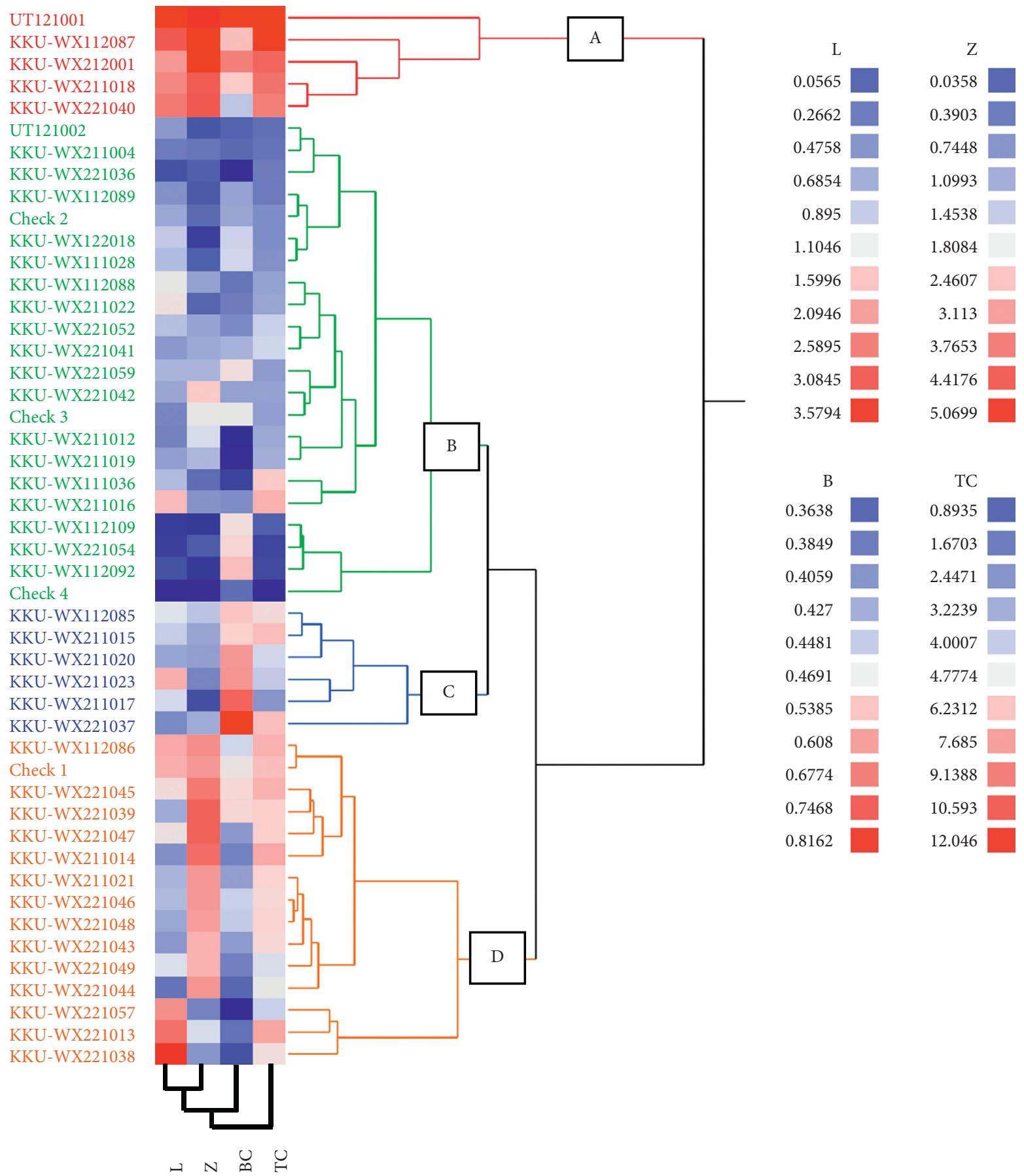

FIgURE 2: Dendogram of phenotypic relationships among 48 small-ear waxy corn genotypes. Four main clusters (A-D) were formed. Twoway Ward's cluster analysis based on lutein (L), zeaxanthin (Z), beta-carotene (BC), and total carotenoids (TC).

The intermediate relationship between $\mathrm{EN}^{1}$ versus $\mathrm{EN}^{2}$ and $\mathrm{EN}^{2} \mathrm{M}$ indicates that the capacity for prolific ears was under the simple genetic control of few genes among individually tested corn accessions. All tested accessions are mostly local-adapted races which are open-pollinated during their successive generations. This study demonstrates that prolificacy is indirectly connected with total grain yield. Previous studies of the use of ear prolificacy as selection criteria to improve total yield have been conducted in field corn [40] and small-ear waxy corn [15].
3.4. Implications for Small-Ear Waxy Corn Germplasm Assessment. Cluster analysis based on multiple carotenoid profiles of the diverse yellow-colored-kernel waxy corn accessions showed that only a few genotypes have complementary higher values of TC, L, Z, and BC, while other genotypes contained poor to low values of these carotenoid fractions. As shown in Figure 3, the selected genotypes were not as orange as either field corn or sweet corn [38]. Since tropical corn contains less BC than temperate corn [41], the five selected accessions from this study could be 
TABLE 4: The carotenoid profiles of top five small-ear waxy corn genotypes based on cluster analysis and four check varieties in two different seasons.

\begin{tabular}{|c|c|c|c|c|c|c|c|c|}
\hline \multirow{2}{*}{ Genotype } & \multicolumn{4}{|c|}{ Rainy $\left(\mu \mathrm{g} \mathrm{g}^{-1} \mathrm{FW}\right)$} & \multicolumn{4}{|c|}{ Dry $\left(\mu \mathrm{g} \mathrm{g}^{-1} \mathrm{FW}\right)$} \\
\hline & $\mathrm{L}$ & Z & $\mathrm{BC}$ & TC & $\mathrm{L}$ & $\mathrm{Z}$ & $\mathrm{BC}$ & TC \\
\hline \multicolumn{9}{|l|}{ Top 5} \\
\hline UT121001 & $4.58 \mathrm{a}$ & $4.90 c$ & $1.19 \mathrm{a}$ & $11.37 \mathrm{~b}$ & $2.58 \mathrm{a}$ & $2.78 \mathrm{bc}$ & $0.44 \mathrm{~b}$ & $9.03 \mathrm{a}$ \\
\hline KKU-WX112087 & $3.20 c$ & $7.26 a$ & $0.66 c-e$ & $18.11 \mathrm{a}$ & $1.40 \mathrm{~cd}$ & $2.88 \mathrm{~b}$ & $0.36 \mathrm{~d}-\mathrm{k}$ & $5.98 b c$ \\
\hline KKU-WX212001 & $1.90 \mathrm{gh}$ & $5.03 \mathrm{~b}$ & $0.74 \mathrm{bc}$ & $7.65 \mathrm{~d}-\mathrm{h}$ & $1.51 \mathrm{c}$ & $3.60 \mathrm{a}$ & $0.43 b$ & $8.09 \mathrm{a}$ \\
\hline KKU-WX211018 & $2.49 \mathrm{de}$ & $3.89 \mathrm{de}$ & $0.63 \mathrm{~d}-\mathrm{g}$ & $9.61 b c$ & $1.22 \mathrm{ef}$ & $2.78 \mathrm{bc}$ & $0.37 c-j$ & $5.45 \mathrm{c}-\mathrm{e}$ \\
\hline KKU-WX221040 & $3.08 c$ & $4.46 \mathrm{~cd}$ & $0.55 f-0$ & $8.94 \mathrm{~cd}$ & $0.90 \mathrm{gh}$ & $2.31 \mathrm{ef}$ & $0.37 \mathrm{c}-\mathrm{j}$ & $5.43 \mathrm{c}-\mathrm{f}$ \\
\hline \multicolumn{9}{|l|}{ Check Varieties } \\
\hline Check 1 & $1.92 \mathrm{~g}$ & $2.39 \mathrm{j}-\mathrm{n}$ & $0.52 \mathrm{~h}-\mathrm{r}$ & $5.66 \mathrm{i}-\mathrm{o}$ & $1.08 \mathrm{f}$ & $2.83 \mathrm{bc}$ & $0.43 b c$ & $5.56 \mathrm{~b}-\mathrm{d}$ \\
\hline Check 2 & $1.15 \mathrm{kl}$ & $1.13 \mathrm{~s}-\mathrm{v}$ & $0.52 \mathrm{~h}-\mathrm{r}$ & $3.880-\mathrm{r}$ & $0.55 n-q$ & $0.53 \mathrm{p}-\mathrm{t}$ & $0.37 c-j$ & $2.89 \mathrm{p}-\mathrm{v}$ \\
\hline Check 3 & $0.941-p$ & $2.93 \mathrm{~g}-\mathrm{j}$ & $0.61 d-h$ & $5.66 \mathrm{i}-\mathrm{o}$ & $0.44 q-\mathrm{s}$ & $0.72 \mathrm{l}-\mathrm{q}$ & $0.33 g-n$ & $2.44 \mathrm{t}-\mathrm{w}$ \\
\hline Check 4 & $0.06 \mathrm{t}$ & $0.02 \mathrm{y}$ & $0.481-\mathrm{r}$ & $1.01 \mathrm{t}$ & $0.05 \mathrm{u}$ & $0.05 x^{1}$ & $0.35 \mathrm{e}-1$ & $0.78 \mathrm{y}$ \\
\hline
\end{tabular}

Both tested accessions and check varieties were ranked on the basis of the overall content of carotenoids fractions. $\mathrm{L}=\mathrm{Lutein}, \mathrm{Z}=\mathrm{Zeaxanthin}, \mathrm{BC}=\mathrm{Beta}-$ carotene, $\mathrm{TC}=$ Total carotenoids, $\mathrm{FW}=$ fresh weight. Means followed by different letters within the same column are significantly different based on LSD at $p \leq 0.05$.

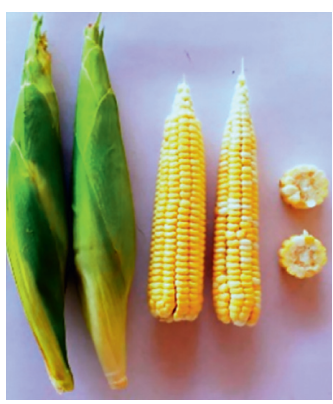

(a)

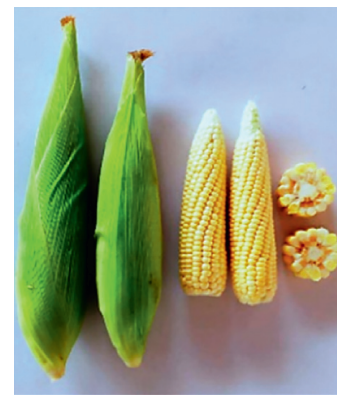

(b)

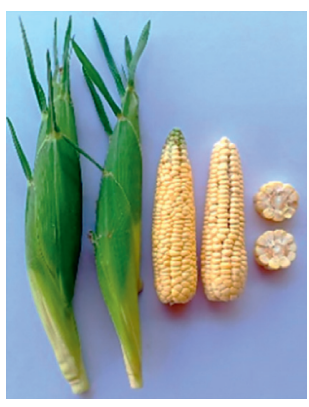

(c)

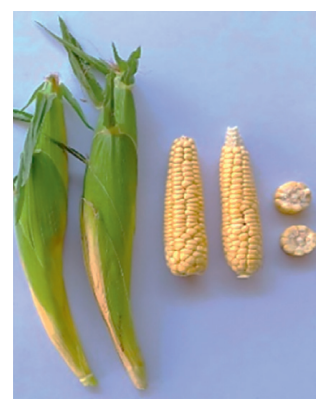

(d)

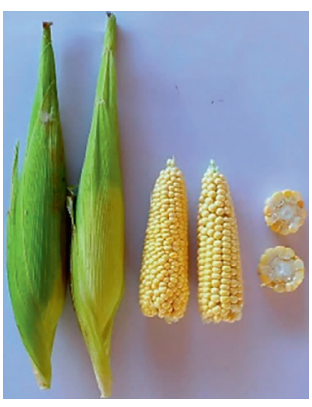

(e)

FIGURE 3: Appearances of both unhusked and husked corn ears of top five genotypes with a high level of lutein, zeaxanthin, beta-carotene, and total carotenoids content. (a) UT121001, (b) KKU-WX112087, (c) KKU-WX212001, (d) KKU-WX211018, and (e) KKU-WX221040.

TABLE 5: Pearson's correlation coefficients between total carotenoids and carotenoids fractions of small-ear waxy corn genotypes.

\begin{tabular}{lccc}
\hline & Lutein & Zeaxanthin & Beta-carotene (ns) \\
\hline Zeaxanthin & $0.39 *$ & & \\
Beta-carotene & $0.03^{\text {ns }}$ & $0.11^{\mathrm{ns}}$ & 0.21 \\
Total carotenoids & $0.69 * *$ & $0.81 * *$ & 0.21 \\
\hline
\end{tabular}

ns: not significant; $*$ significant at $p \leq 0.05 ; * *$ significant at $p \leq 0.01$.

intercrossed with temperate corn germplasm that has high levels of carotenoids. Progress for increasing carotenoid content could be rapid, as indicated by the low environment, and $\mathrm{G} \times \mathrm{E}$ effects revealed, in this study, high heritability estimates [30] and predominant additive genetic effects [14].

Although biofortification is primarily directed to the breeding of staple food crops to increase specific nutrient levels [42], other important keys to success are (i) developing profitable biofortified varieties and (ii) acceptable to farmers and consumers [43]. Developing biofortified small-ear waxy corn with two marketable ears is an indirect approach to achieve high yielding, profitable varieties that fall within farmer preferences, whereas better cooking and eating qualities will meet consumer preferences. Therefore, one of the future research directions is performing blind sensory tests to assess consumer preferences such as aroma, stickiness, tenderness, and overall-liking. We expect that the future biofortified orange small-ear waxy corn will be not only superior at providing carotenoids for daily human intake but also profitable to farmers and palatable to consumers. 


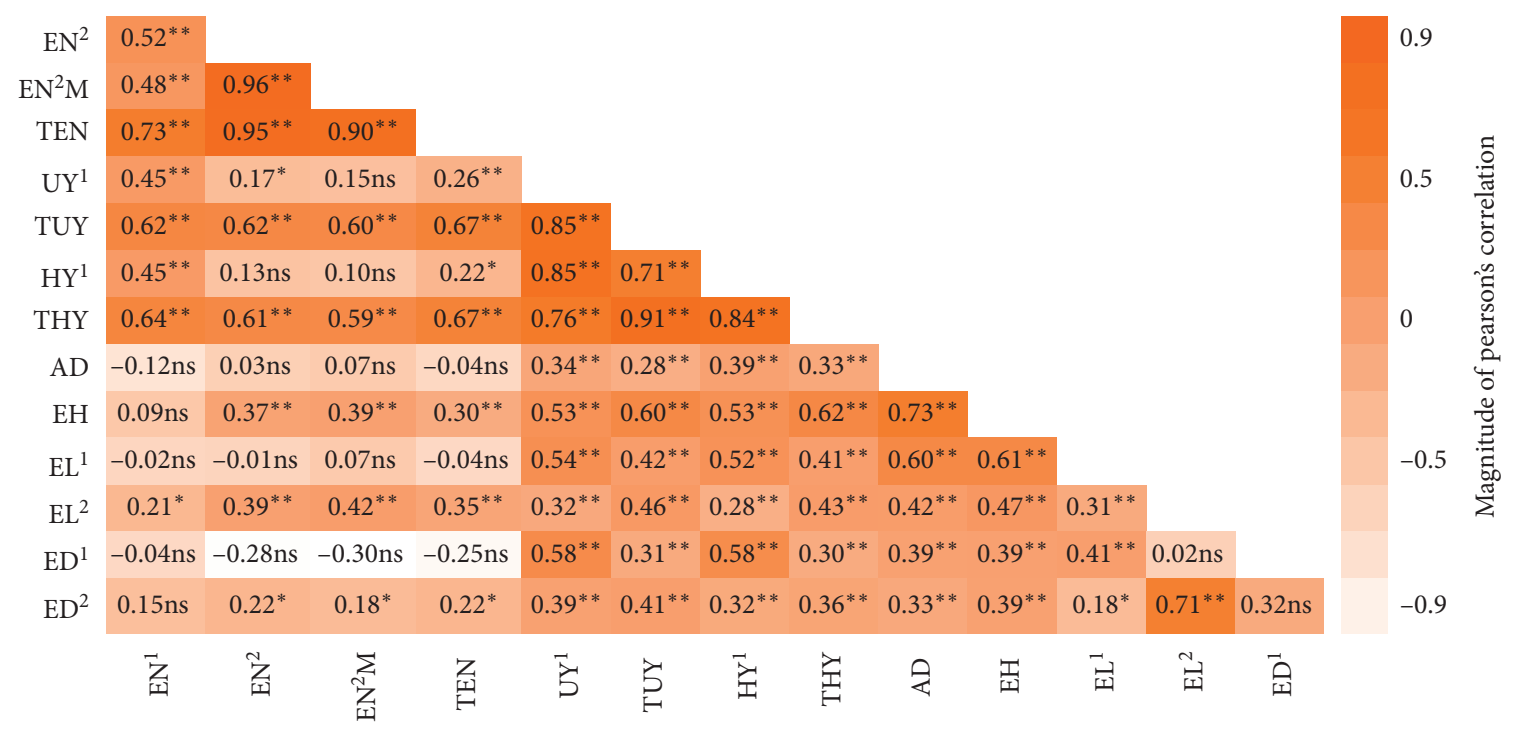

Figure 4: Triangular heat map representing Pearson's correlation coefficients between yields, yield components, and agronomic characters of small-ear waxy corn genotypes. $\mathrm{EN}^{1}=$ ear number at the first ear position, $\mathrm{EN}^{2}=$ ear number at the second ear position, $\mathrm{EN}^{2} \mathrm{M}=$ marketable ear number at the second ear position, TEN $=$ total of ear number, $\mathrm{UY}^{1}=$ unhusked yield of the first ear position, TUY = total of unhusked yield, $\mathrm{HY}^{1}=$ husked yield of the first ear position, $\mathrm{THY}=$ total of husked yield, $\mathrm{AD}=$ anthesis date, $\mathrm{EH}=\mathrm{ear}$ height, $\mathrm{EL}^{1}=$ husked ear length of the first ear position, $\mathrm{EL}^{2}=$ husked ear length of the second ear position, $\mathrm{ED}^{1}=$ husked ear diameter of the first ear position, $\mathrm{ED}^{2}=$ husked ear diameter of the second ear position. ns $=$ not significant; $*$ and $* *$ significant at $p=0.05$ and $p=0.01$, respectively.

\section{Conclusions}

Forty-eight accessions of small-ear waxy corn could be clustered into four major groups regarding the similarity of multiple carotenoids profiles. Three selected accessions, namely, UT121001, KKU-WX112087, and KKUWX212001, had higher values of total carotenoids, lutein, zeaxanthin, and beta-carotene than those of all check varieties. The strategies for small-ear waxy corn selection improved for carotenoids and prolific ears are comprised of three steps, namely, (i) performing visual selection twice for prolificacy at the early silking stage and during grain filling in the field, (ii) conducting visual selection in the field against white to pale yellow corn kernels, and (iii) assigning total carotenoids as an indirect selection to improve non-provitamin A carotenoid concentrations such as lutein and zeaxanthin.

\section{Data Availability}

All data analyzed to support the findings of this research are included in this research article.

\section{Disclosure}

The funding sponsors had no role in the design of the study; in the collection, analyses, or interpretation of data; in the writing of the manuscript; and in the decision to publish the results.

\section{Conflicts of Interest}

The authors declare no conflicts of interest.

\section{Acknowledgments}

The research was financially supported by the Thailand Research Fund through the Royal Golden Jubilee Ph.D. Program (Grant no. PHD/0214/2560) and the Senior Research Scholar Project of Prof. Dr. Sanun Jogloy (Project no. RTA6180002). This research was supported in part by the U.S. Department of Agriculture, Agricultural Research Service. USDA is an equal opportunity employer. Mention of trade names or commercial products in this report is solely for the purpose of providing specific information and does not imply recommendation or endorsement by the U.S. Department of Agriculture. The authors would like to thank the National Science and Technology Development Agency (NSTDA), Thailand (Grant no. P-17-51695); Uthai Thani Agricultural Research and Development Center, Uthai Thani, Department of Agriculture (DOA), Thailand; and the Plant Breeding Research Center for Sustainable Agriculture, Faculty of Agriculture, Khon Kaen University, Thailand, for providing plant materials and research facilities. The authors are thankful to Mr. Abil Dermail for proofreading and critical discussion.

\section{References}

[1] G. R. Dagenais, R. Marchioli, G. Tognoni, and S. Yusuf, "Betacarotene, vitamin $\mathrm{C}$, and vitamin $\mathrm{E}$ and cardiovascular diseases," Current Cardiology Reports, vol. 2, no. 4, pp. 293-299, 2000.

[2] H. N. Basu, A. J. D. Vecchio, F. Flider, and F. T. Orthoeter, "Nutritional and potential disease prevention properties of carotenoids," Journal of the American Oil Chemists' Society, vol. 78, no. 7, pp. 665-675, 2001, https://www.scimagojr.com/ journalsearch.php?q=25881\&tip=sidvol. 
[3] P. Palozza and N. I. Krinsky, "Antioxidant effects of carotenoids in vivo and in vitro: an overview," Methods in Enzymology, vol. 213, pp. 403-420, 1992.

[4] C. O. Egesel, J. C. Wong, R. J. Lambert, and T. R. Rocheford, "Combining ability of maize inbreds for carotenoids and tocopherols," Crop Science, vol. 43, no. 3, pp. 818-823, 2003.

[5] G. J. Handelman, E. A. Dratz, C. C. Reay, and F. J. G. M van Kujik, "Carotenoids in the human macula and whole retina," Investigative Ophthalmology \& Visual Science, vol. 29, pp. 850-855, 1988.

[6] H. Gerster, "Potential role of beta-carotene in the prevention of cardiovascular disease," International journal for vitamin and nutrition research. Internationale Zeitschrift Fur Vitaminund Ernahrungsforschung. Journal international de vitaminologie et de nutrition, vol. 61, no. 4, pp. 277-291, 1991.

[7] B. Buckner, P. S. Miguel, D. Janick-Buckner, and J. L. Bennetzen, "The $y 1$ gene of maize codes for phytoene synthase," Genetics, vol. 143, pp. 479-488, 1996.

[8] K. Lertrat and N. Thongnarin, "Novel approach to eating quality improvement in local waxy corn: improvement of sweet taste in local waxy corn variety with mixed kernels from super sweet corn," Acta Horticulturae, vol. 769, no. 769, pp. 145-150, 2008.

[9] V. Fergason, "High amylose and waxy corns," in Specialty Corns, A. R. Hallauer, Ed., pp. 71-92, CRC Press, New York, NY, USA, 2nd edition, 2001.

[10] Q.-p. Hu and J.-g. Xu, "Profiles of carotenoids, anthocyanins, phenolics, and antioxidant activity of selected color waxy corn grains during maturation," Journal of Agricultural and Food Chemistry, vol. 59, no. 5, pp. 2026-2033, 2011.

[11] K. Chandler, A. E. Lipka, B. F. Owens et al., "Genetic analysis of visually scored orange kernel color in maize," Crop Science, vol. 53, no. 1, pp. 189-200, 2013.

[12] A. Junpatiw, K. Lertrat, K. Lomthaisong, and R. Tangwongchai, "Effects of steaming, boiling and frozen storage on carotenoid contents of various sweet corn cultivars," International Food Research Journal, vol. 20, pp. 2219-2225, 2013.

[13] K. Pillay, J. Derera, M. Siwela, and F. Veldman, "Consumer acceptance of yellow, provitamin A-biofortified maize in KwaZulu-Natal," South African Journal of Clinical Nutrition, vol. 24, no. 4, pp. 186-191, 2011.

[14] A. D. Halilu, S. G. Ado, D. A. Aba, and I. S. Usman, "Genetics of carotenoids for provitamin A biofortification in tropicaladapted maize," The Crop Journal, vol. 4, no. 4, pp. 313-322, 2016.

[15] P. Kesornkeaw, K. Lertrat, and B. Suriharn, "Response to four cycles of mass selection for prolificacy at low and high population densities in small ear waxy corn," Asian Journal of Plant Sciences, vol. 8, no. 6, pp. 425-432, 2009.

[16] M. E. Sorrells, J. H. Lonnquist, and R. E. Harris, "Inheritance of prolificacy in maize 1," Crop Science, vol. 19, no. 3, pp. 301-306, 1979.

[17] C. T. Senete, P. E. d. O. Guimarães, M. C. D. Paes, and J. C. d. Souza, "Diallel analysis of maize inbred lines for carotenoids and grain yield," Euphytica, vol. 182, no. 3, pp. 395-404, 2011.

[18] B. Harakotr, B. Suriharn, M. P. Scott, and K. Lertrat, "Genotypic variability in anthocyanins, total phenolics, and antioxidant activity among diverse waxy corn germplasm," Euphytica, vol. 203, no. 2, pp. 237-248, 2015.

[19] P. Schaub, P. Beyer, S. Islam, and T. Rocheford, "Maize quick carotenoid extraction protocol," 2004, http://www.cropsci. illinois.edu/faculty/rocheford/quickcarotenoid_analysis\%20_ protocol.pdf.

[20] P. Gupta, Y. Sreelakshmi, and R. Sharma, "A rapid and sensitive method for determination of carotenoids in plant tissues by high performance liquid chromatography," Plant Methods, vol. 11, pp. 1-5, 2015.

[21] D. B. Rodriguez-Amaya and M. Kimura, "Harvest plus handbook for carotenoids analysis,", in HarvestPlus Technical Monographs; IFPRI and CIATInternational Food Policy Research Institute, Washington DC, USA, 2004.

[22] K. A. Gomez and A. A. Gomez, Statistical Procedure for Agricultural Research, p. 680, John Wiley and Sons, Singapore, 1984.

[23] R. Bernardo, Breeding for Quantitative Traits in Plants, pp. 175-202, Stemma Press, Woodbury, MN, USA, 2020.

[24] SAS Institute Inc., JMP Trial 15.0.0 (403428), SAS Institute Inc., 2019, http://www.jmp.com.

[25] Statistix 10 Analytical Software, Tallahassee, FL, USA, 2013, http://statistix.com.

[26] L. F. Bauman, "Relative yields of first (apical) and second ears of semi-prolific southern corn hybrids 1," Agronomy Journal, vol. 52, no. 4, pp. 220-222, 1960.

[27] J. Derera, P. Tongoona, B. S. Vivek, and M. D. Laing, “Gene action controlling grain yield and secondary traits in southern African maize hybrids under drought and non-drought environments," Euphytica, vol. 162, no. 3, pp. 411-422, 2008.

[28] A. Menkir, W. Liu, W. S. White, B. Maziya-Dixon, and T. Rocheford, "Carotenoid diversity in tropical-adapted yellow maize inbred lines," Food Chemistry, vol. 109, no. 3, pp. 521-529, 2008.

[29] T. Muzhingi, N. Palacios-Rojas, A. Miranda, M. L. Cabrera, K.-J. Yeum, and G. Tang, "Genetic variation of carotenoids, vitamin $\mathrm{E}$ and phenolic compounds in provitamin A biofortified maize," Journal of the Science of Food and Agriculture, vol. 97, no. 3, pp. 793-801, 2017.

[30] S. Chander, Y. Q. Guo, X. H. Yang et al., "Using molecular markers to identify two major loci controlling carotenoid contents in maize grain," Theoretical and Applied Genetics, vol. 116, no. 2, pp. 223-233, 2008.

[31] M. E. Otegui, M. G. Nicolini, R. A. Ruiz, and P. A. Dodds, "Sowing date effects on grain yield components for different maize genotypes," Agronomy Journal, vol. 87, no. 1, pp. 29-33, 1995.

[32] L. M. Smith, "The heat is on: maize pollen development after a heat wave," Plant Physiology, vol. 181, no. 2, pp. 387-388, 2019.

[33] A. R. Hallauer and A. F. Troyer, "Prolific corn hybrids and minimizing risk of stress," in Proceeding of Annual Corn \& Sorghum Research, Conference, 27th ASTA, pp. 140-158, Washington, DC, USA, 1972.

[34] T. Sun, H. Yuan, H. Cao, M. Yazdani, Y. Tadmor, and L. Li, "Carotenoid metabolism in plants: the role of plastids," Molecular Plant, vol. 11, no. 1, pp. 58-74, 2017.

[35] W. B. Suwarno, K. V. Pixley, N. Palacios-Rojas, S. M. Kaeppler, and R. Babu, "Formation of heterotic groups and understanding genetic effects in a provitamin A biofortified maize breeding program," Crop Science, vol. 54, no. 1, pp. 14-24, 2014.

[36] R. Vallabhaneni, C. E. Gallagher, N. Licciardello, A. J. Cuttriss, R. F. Quinlan, and E. T. Wurtzel, "Metabolite sorting of a germplasm collection reveals the hydroxylase 3 locus as a new target for maize provitamin a biofortification," Plant Physiology, vol. 151, no. 3, pp. 1635-1645, 2009.

[37] J.-G. Xu, Q.-P. Hu, X.-D. Wang, J.-Y. Luo, Y. Liu, and C.-R. Tian, "Changes in the main nutrients, phytochemicals, 
and antioxidant activity in yellow corn grain during maturation," Journal of Agricultural and Food Chemistry, vol. 58, no. 9, pp. 5751-5756, 2010.

[38] T. J. O'Hare, K. J. Fanning, and I. F. Martin, "Zeaxanthin biofortification of sweet-corn and factors affecting zeaxanthin accumulation and colour change," Archives of Biochemistry and Biophysics, vol. 572, pp. 184-187, 2015.

[39] J. I. Sarquís, H. Gonzalez, and J. R. Dunlap, "Yield response of two cycles of selection from a semiprolific early maize (Zea mays L.) population to plant density, sucrose infusion and pollination control," Field Crops Research, vol. 55, no. 1-2, pp. 109-116, 1998.

[40] N. Leon and J. G. Coors, "Twenty-four cycles of mass selection for prolificacy in the golden glow maize population," Crop Science, vol. 42, no. 2, pp. 325-333, 2002.

[41] K. Pixley, N. P. Rojas, R. Babu, R. Mutale, R. Surles, and E. Simpungwe, "Biofortification of maize with provitamin A carotenoids," in Carotenoids and Human Health, Nutrition and Health, S. A. Tanumihardjo, Ed., pp. 271-292, Springer Science + Business Media, New York, NY, USA, 2013.

[42] W. H. Pfeiffer and B. McClafferty, "Harvest plus: breeding crops for better nutrition," Crop Science, vol. 47, pp. S-88, 2007.

[43] H. E. Bouis and R. M. Welch, "Biofortification-A sustainable agricultural strategy for reducing micronutrient malnutrition in the global South," Crop Science, vol. 50, pp. S-20, 2010. 